\title{
PEAT HUMIFICATION CHARACTER IN TWO OMBROTROPHIC BOGS DEPENDING ON PEAT PROPERTIES
}

\author{
Inese Silamiḳele, Oḷǵerts Nikodemus, Laimdota Kalniṇa, Oskars Purmalis, \\ and Māris Kḷaviṇš \\ Faculty of Geographical and Earth Sciences, University of Latvia, Raina bulv. 19, LV-1586, Rĩga, LATVIA
}

Contributed by Māris Kḷaviṇš

\begin{abstract}
Study of the living organic matter humification process is essential for understanding of the carbon biogeochemical cycle. The aim of this study is to determine the relations between peat properties and humification degree in two peat profiles in ombrotrophic bogs in Latvia, to identify the links between peat age, decomposition degree, peat properties, peat botanical composition and peat properties. The peat diagenesis process was described using multiproxy analysis of peat age, botanical composition, elemental composition, elemental ratios of the peat organic matter and peat alkaline extracts. This approach supports a better understanding of the peat properties and their relation both to peat decomposition processes, and also to original living organic matter. Multiproxy study of peat properties supports development of peat humification indicators.
\end{abstract}

Key words: peat, Latvia, humification indicators, multiproxy study.

\section{INTRODUCTION}

A key process in the carbon biogeochemical cycle is the transformation of living organic matter into the refractory part of organic matter - humic substances (humic acid, fulvic acid, and humin). Both degradation and synthetic processes during decay of living organic matter are described as humification and in general it describes transformation of numerous groups of substances (proteins, carbohydrates, lipids etc.) and individual molecules present in living organic matter into groups of substances with similar properties (humic substances) and finally into mineral carbon compounds. Understanding of transformation of living organic matter until their mineralisation, and especially formation of humic substances, are of key importance to understand carbon biogeochemical cycling (Francioso et al., 2003). It is important to study humification processes in conditions where the transformation of living organic matter can be studied in a relatively homogeneous and stable environment, such as in peat of bogs.

Peat is a light brown to black organic material formed under waterlogged conditions from the partial decomposition of mosses and other bryophytes, sedges, grasses, shrubs, or trees (Coccozza et al. 2003). Interest inpeat properties is growing since peat as a substance supports and influences bog and wetland ecosystems, and peat monoliths can serve as an archive indicating conditions in past environments (Yeloff and Mauquoy 2006). Peat conains significant amounts of stored organic carbon and thus peat reserves play a major role in the carbon biogeochemical cycling and have a special role in climate change (Borgmark, 2005b).
Industrial and agricultural uses of peat are growing (Ghaly et al., 1999; Brown et al., 2000) and significant amounts of peat are mined industrially not only in Northern countries, but also in tropical regions. Considering this, there is an increasing interest into studies of peat properties and processes influencing their formation. During peat development, even at a specific site major changes in vegetation, temperature, amount of precipitations and correspondingly of the bog hydrological conditions, land use changes in the basin of wetland can take place (Caseldine et al., 2000; Chapman et al., 2001; Zaccone et al., 2007).

To characterise the humification process, an important tool can be development of humification indexes linking the rate of transformation of living organic matter, development of humic substances with parameters describing properties of formed materials (Lu et al., 2001). Several humification indexes have been suggested to study the humification process during composting to evaluate maturity of compost (Jerzykiewicz et al. 1999; Domeizel et al., 2004) and study soil formation processes (Zsolnay et al., 1999; Cavani et al., 2003; Ikeya and Watanabe, 2003; Rosa et al., 2005; Corvasce et al., 2006). Usually the humification process is evaluated using indirect measurements describing structural changes occurring during the humification process. Several methods have been suggested to describe the humification, such as measurement of the $\mathrm{E}_{4} / \mathrm{E}_{6}$ ratio indicating development of condensed macromolecules, and amount of organic /aliphatic carbon estimated by ${ }^{13} \mathrm{C} \mathrm{CP}$ MAS NMR. Also presence of free radicals, determined using EPR and studies of fluorescence properties of humic macromolecules has been used to describe humification processes (Milori et al., 
2002). However, humification processes of peat have been studied only in few articles (Schnitzer and Levesque, 1979; Preston et al., 1989; Hargitai, 1994; Baran, 2002; Francioso et al., 2003; Šire et al., 2008), which is surprising considering that bogs and wetlands form one of the largest sources of refractory organic matter.

The aim of this study was to determine the relations between peat properties and humification degree in two peat profiles of ombrotrophic bogs in Latvia.

\section{MATERIALS AND METHODS}

Site location. The study area includes ombrotrophic bogs located in the central part (Rīga District) of Latvia (Fig. 1). The bogs are located in the Coastal Latvia Lowland and their origin is similar and characteristic not only for ombrotrophic bogs in Latvia, but also for the North European region. Indepth studies were made on two bogs - Eipurs and Dzelves-Kronu bogs. The two bogs have developed by ground paludification after the Ice age. Presently, the bogs are typical raised bogs with a number of bog lakes and pools. Dzelves-Kronu Bog (coordinates N 57 $13^{\prime}$ 58,2", E $\left.024^{\circ} 30^{\prime} 12,2^{\prime \prime}\right)$ is in a semi pristine condition in spite of peat cutting areas in the north-western part. Eipurs Bog (coordinates N $57^{\circ} 14^{\prime} 53,4^{\prime \prime}$, E $024^{\circ} 37^{\prime} 00,3^{\prime \prime}$ ) is influenced by drainage and peat cutting, and the largest part is covered by pine forest.

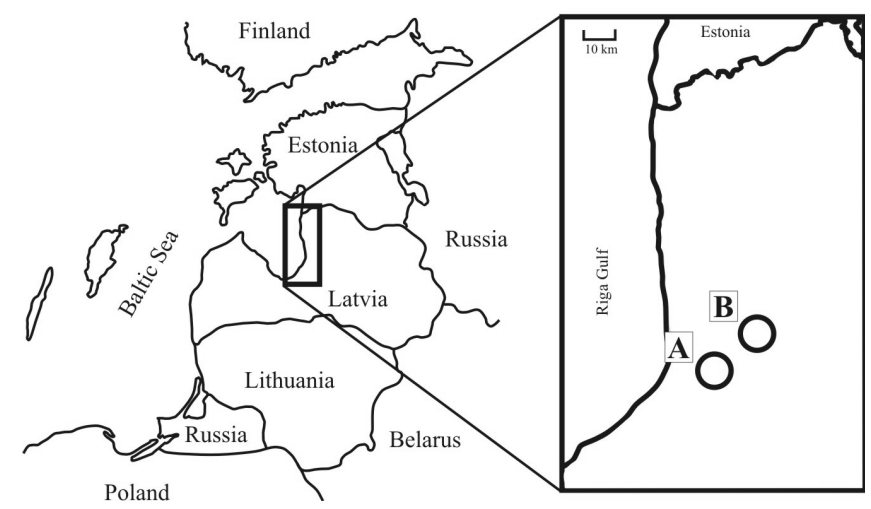

Fig. 1. Sampling sites: A - Dzelves-Kronu bog; B - Eipurs bog.

The maximal depth of the peat layer in Eipurs bog is $4.70 \mathrm{~m}$. The bog is in the transformation process from raised bog to Pinus sylvestris forest. Among the mosses the Sphagnum species, S. fuscum and S. magellanicum, dominate.

Dzelves-Kroņu Bog is a developing raised bog and is included in the list of Natura 2000 protected areas. In the sampling area, the plant communities are typical of a raised bog with hummocks covered by Sphagnum moss and hollows and small bog lakes. Dzelves-Kronu bog is an active raised bog and is included in the list of Natura 2000 protected areas.

Sampling. Sampling was made using previously suggested approaches for peat core sampling to study peat properties
(Borgmark, 2005b). Coring and peat sampling was conducted by peat sampler in the cupola area of each bog, where the surface peat layers are clearly elevated up to 2-4 $\mathrm{m}$ above that at the edge of the bog and has not been influenced by peat sliding. The peat samples $(50 \mathrm{~cm}$ long monoliths) were placed in a special cartridge and wrapped in polyethylene film to preserve natural moisture, brought to the laboratory and sliced into $3 \mathrm{~cm}$ sections using a stainless steel knife. The outside edges were systematically discarded, as those could have been contaminated during the sampling. The first slice ( +3 to $0 \mathrm{~cm}$ ) corresponds to the living plant material on the bog surface. The peat material was oven dried at $105{ }^{\circ} \mathrm{C}$ in Teflon bowls and ground in a centrifugal mill.

Peat botanical composition. Peat botanical composition is closely related to plant nutrition conditions, characteristics of bog depression, relief, underlying deposits and groundwater mineralisation degree, which substantially affect peat decomposition degree, moisture and properties (Тюремнов, 1976).

The analysis of botanical composition was performed using a Carl-Zeiss binocular microscope and the decomposition degree (Lishtvan and Korol, 1975) was determined using common methods. Peat type and H-value (according to von Post and Granlund, 1926) were determined in the field and later adjusted in the laboratory.

Analysis of peat properties. The ${ }^{14} \mathrm{C}$ dating was conducted at the Institute of Geology of the Tallinn Technical University (Estonia). Carbon, hydrogen, nitrogen and sulphur concentrations in peat samples (elemental analysis of C, H, N, S) was carried out using an Elemental Analyzer Model EA-1108 (Carlo Erba Instruments) by combustion-gas chromatography technique. The instrument was calibrated using cystine (Sigma - Aldrich Inc.) and all peat samples were analysed in duplicate. Ash content was measured after heating $50 \mathrm{mg}$ of each peat sample at $750{ }^{\circ} \mathrm{C}$ for $8 \mathrm{~h}$. Elemental composition was corrected considering the ash content, and the oxygen amount was calculated as a difference. Elemental analysis has been used to calculate elemental ratios and degree of oxidation $\omega$ (Fong and Mohamed, 2007) and index of hydrogen deficiency $\phi$.

$\phi=\frac{(2 C+2)-H}{2}$

$\omega=(2 O+3 N)-\frac{H}{C}$

UV/Vis spectra were recorded on a Thermospectronic Helios $\gamma$ UV (Thermoelectron Co) spectrophotometer in a 1-cm quartz cuvette. The $\mathrm{E}_{4} / \mathrm{E}_{6}$ ratio (Chen et al., 1977): ratio of absorbance at 465 and $665 \mathrm{~nm}$ was determined for extracts of $0.25 \mathrm{~g}$ of peat in $10 \mathrm{ml}$ of $0.05 \mathrm{M} \mathrm{NaOH}$.

Organic carbon concentration of peat extracts was determined using a Shimadzu TOC - VCSN. 


\section{Humification degree}

Humification degree (HD) according to Blackford and Chambers, 1993, as modified by Borgmark 2005: $1.00 \mathrm{~g}$ of peat sample was treated for $1.5 \mathrm{hrs}$ with $25 \mathrm{ml}$ of $8 \% \mathrm{NaOH}$ in $25 \mathrm{ml}$ plastic tubes in a boiling water bath $\left(95^{\circ} \mathrm{C}\right)$ and filtered. $12.5 \mathrm{ml}$ of the filtrate were diluted to $100 \mathrm{ml}$ and absorption was measured at $540 \mathrm{~nm}$. The peat humification degree was expressed as absorption.

Humification degree according to Šire et al., 2008: $1.00 \mathrm{~g}$ of peat sample was shaken for $24 \mathrm{hrs}$ with $50 \mathrm{ml}$ of $1.0 \mathrm{M}$ $\mathrm{NaOH}$, filtered and in the filtrate the total organic carbon of the alkaline extract, containing humic substances $\left(\mathrm{C}_{\mathrm{HS}}\right)$ was determined $(\mathrm{mg} \mathrm{C} / \mathrm{g})$. The peat humification degree was calculated as:

$H D=\frac{C_{H S}}{C_{\text {peat }}} \times 100$, where $\mathrm{C}$ is carbon in the sample $(\mathrm{mg} / \mathrm{g})$

Data treatment. Statistical analyses were performed using SPSS 16 Software. The fit of the obtained data to the normal distribution was checked with the KolmogorovSmirnov tests. In further analysis non-parametric methods were used. Relationships between different characteristics were assessed by Spearman rank correlation coefficients. In all cases the significance level was $P=0.05$.

\section{RESULTS}

The results of the paleobotanical investigations (botanical composition, pollen analysis) indicate both differences and similarities of bog development and peat properties. KronuDzelve Bog was formed by paludification of sandy ground after a raised groundwater level and wet conditions in a small depression. A raised bog cotton grass peat layer covers the sandy bottom, which is overlain by pine-cotton grass peat. The upper part of peat section is represented by a 3.2 $\mathrm{m}$ thick Sphagnum fuscum peat layer with a decomposition level 9 to $17 \%$ (Fig. 2). Botanical composition is not very variable: Sphagnum fuscum (60-75\%), Eriophorum vaginatum 10-15\%, Sphagnum rubellum 10-15\% and dwarf shrubs 10-15\%. The botanical composition of Eipurs Bog differs, although its origin is similar (Fig. 3). The deepest part of Eipurs is formed by fen wood-grass peat, Hypnum and sedge-Hypnum peat (Fig. 3) which is covered by a transition type wood peat. The upper part is represented by $3.45 \mathrm{~m}$ thick raised bog peat of different types and decomposition degree. For example, well decomposed (40-48\%) pine-cotton grass peat occurs at a depth of 1.18-1.39 m (Fig. 3), which possibly accumulated during the second climatic optimum. Although these bogs are located comparatively close, their local conditions for peat formation have been different. Pollen data indicate the start of development during the late Atlantic Period or the subboreal. The surface vegetation of the studied bogs is typical for ombrotrophic bogs in Latvia and in detail is described elsewhere (Silamikele et al., 2008).

The elemental composition of the studied peat cores are summarised in Figure 4 and Table 1. The ash content in the

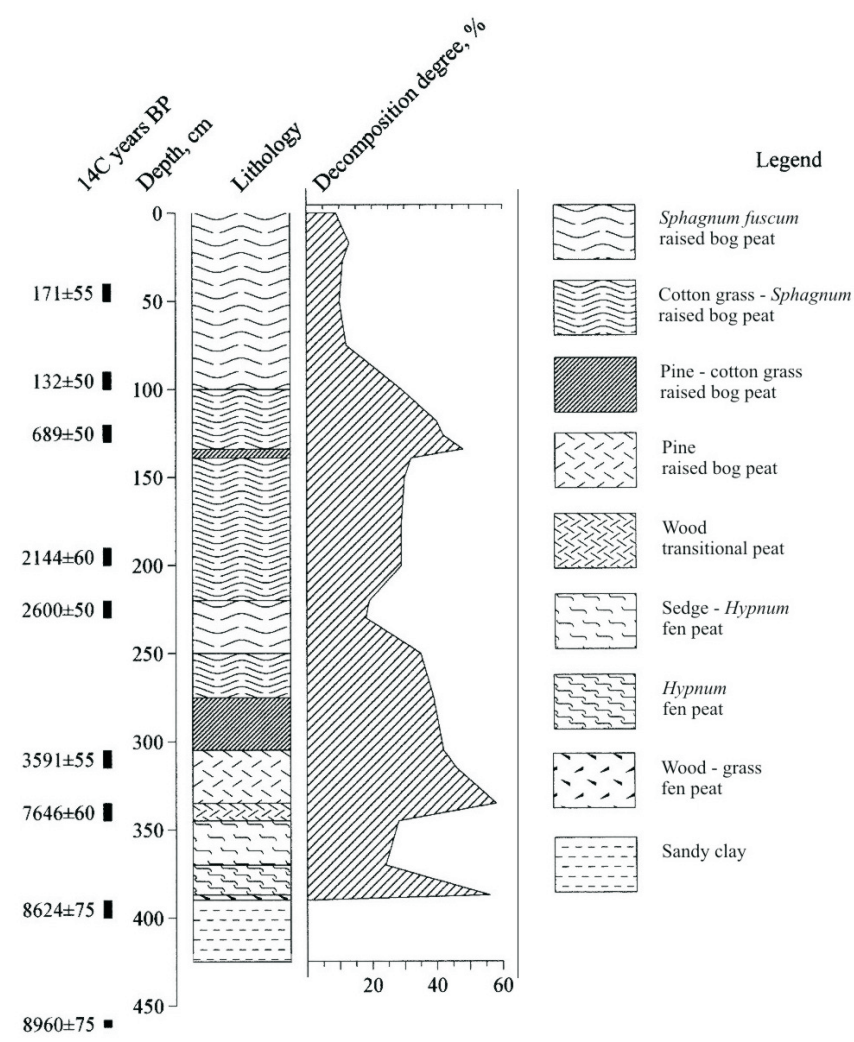

Fig. 2. Peat stratigraphy in Eipurs bog.

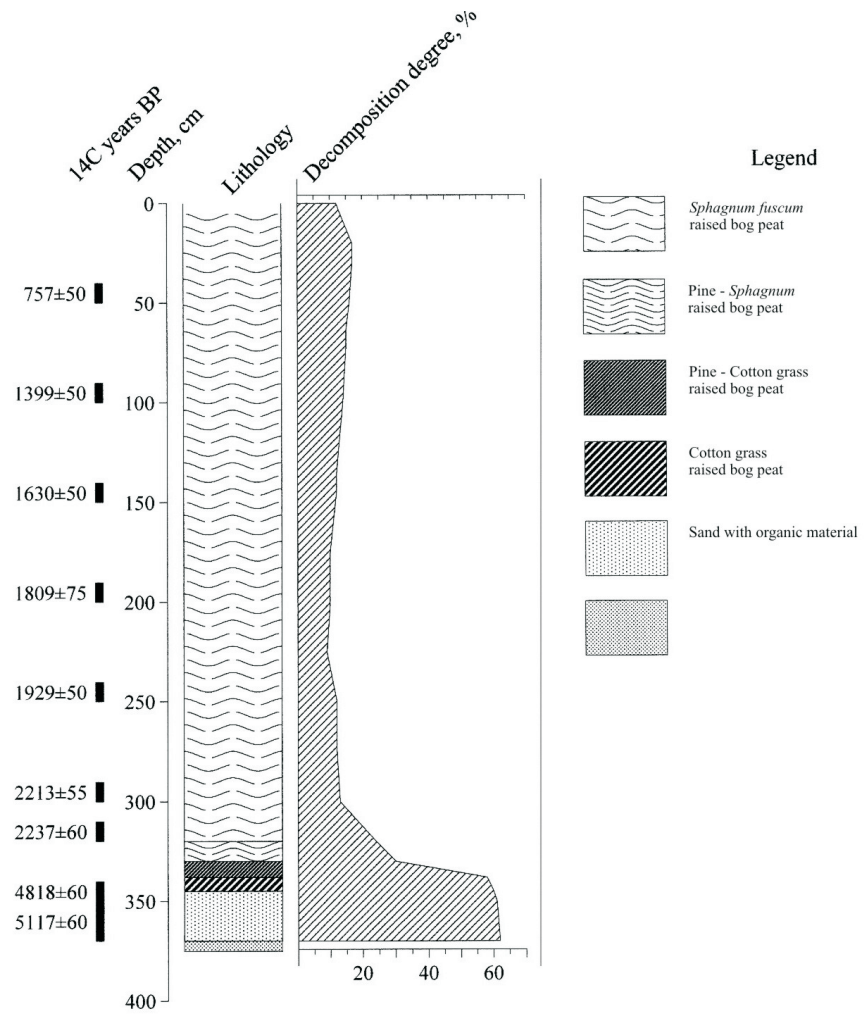

Fig. 3. Peat stratigraphy in Kroņu-Dzelves bog.

studied bogs ranged between $0.30 \pm 0.05 \%$ and $6.10 \pm$ $0.05 \%$, with an average content of $1.8 \pm 0.05$ and the $\mathrm{C}$ concentration from 40 to $55 \%$ and $\mathrm{H}$ from 5.4 to $6.7 \%, \mathrm{~N}$ from 0.5 to $1.5 \%, \mathrm{~S}$ from 0.2 to $1.7 \%$, and $\mathrm{O}$ from 38 to $49 \%$. 

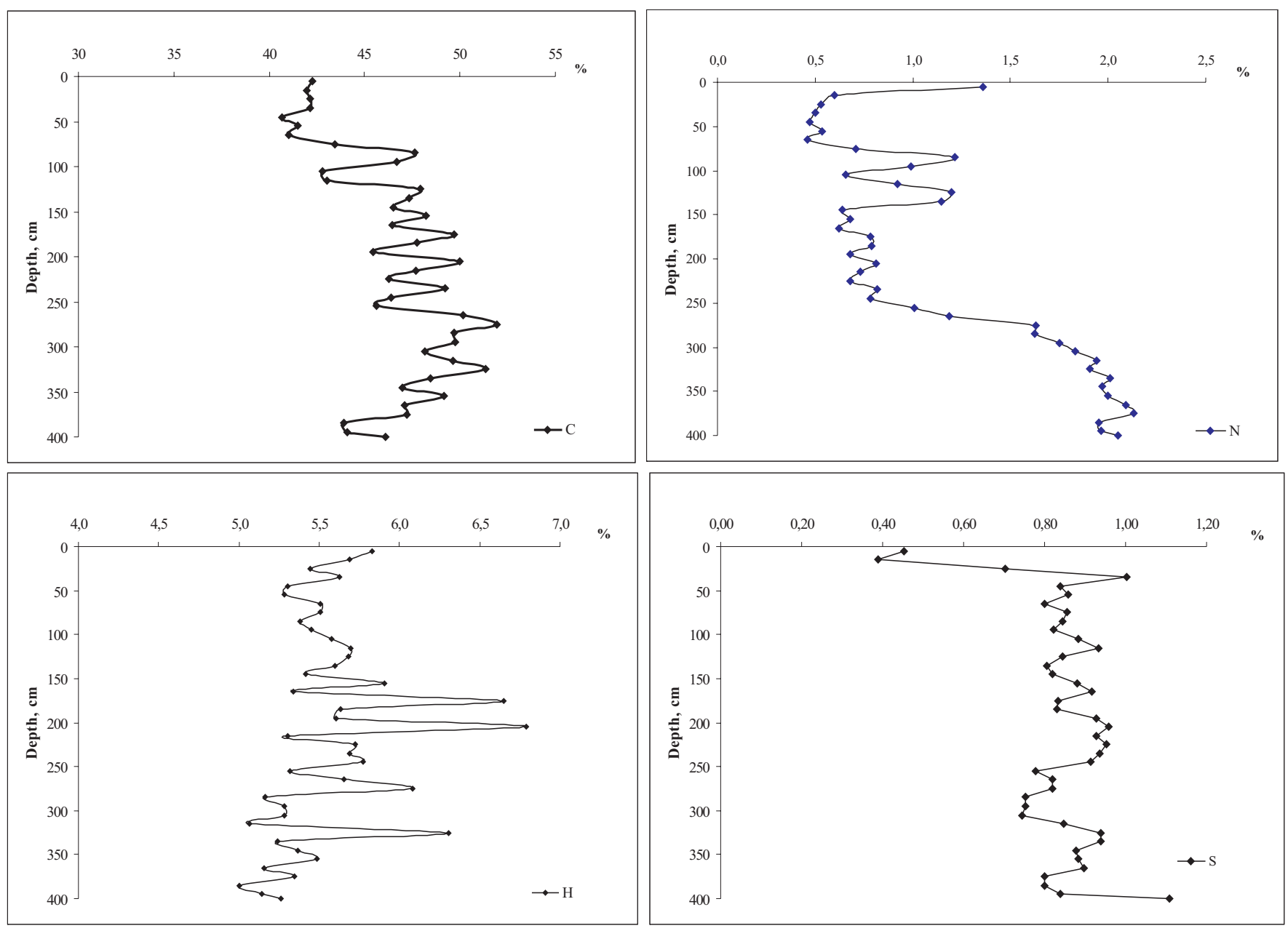

Fig. 4. Elemental composition of Eipurs bog peat.

Table 1

PEAT DECOMPOSITION DEGREE AND ELEMENTAL COMPOSITION OF PEAT IN KRONUU-DZELVES BOG

\begin{tabular}{r|c|c|c|c|c}
\hline Depth, cm & $\begin{array}{c}\text { Decomposi- } \\
\text { tion, \% }\end{array}$ & $\mathrm{C}, \%$ & $\mathrm{H}, \%$ & $\mathrm{~N}, \%$ & $\mathrm{~S}, \%$ \\
\hline-5 & 12 & 44.77 & 5.91 & 0.73 & 0.89 \\
-105 & 14 & 45.68 & 5.78 & 0.53 & 0.88 \\
-160 & 12 & 46.05 & 5.81 & 0.55 & 0.88 \\
-205 & 10 & 45.53 & 5.60 & 0.47 & 0.81 \\
-240 & 9 & 44.84 & 5.47 & 0.45 & 0.88 \\
-305 & 13 & 47.42 & 5.75 & 0.76 & 0.87 \\
-320 & 12 & 45.73 & 5.55 & 0.62 & 1.22 \\
-325 & 24 & 44.73 & 5.44 & 0.60 & 0.64 \\
-335 & 30 & 52.10 & 5.20 & 1.51 & 0.73 \\
-340 & 38 & 52.70 & 5.20 & 1.70 & 0.77 \\
-350 & 60 & 55.53 & 6.20 & 1.23 & 1.19
\end{tabular}

Element ratios were used to characterise peat composition (Fig. 5). $\mathrm{H} / \mathrm{C}$ and $\mathrm{O} / \mathrm{C}$ values showed a decreasing trend with peat depth and N/C ratio in general increased with depth of the peat core. However, this ratio is high in the upper layer (possibly due to the presence of proteinaceous materials of living organic matter), variable with increasing depth (starting from $250 \mathrm{~cm}$ ), but increased in more decom- posed peat layers. This demonstrates that atomic ratio cannot be used alone to study the humification process due to the significant impact of the original plant composition and peat formation conditions.

\section{DISCUSSION}

Studies of living organic material transformation (humification) is of utmost importance for better understanding of carbon biogeochemical cycling. From this perspective studies are needed on peat properties in cores and identification and the links or correlations between peat age, decomposition degree, peat properties, peat botanical composition (describing and much depending on the bog development conditions, climatic and hydrological factors as well as changes of land use within the bog catchment). Important are also information on changes of peat properties that describe humification process at the molecular level, which can provide new understanding of chemical and biochemical processes behind the humification. We selected two ombrotrophic bogs of similar age, located spatially closely (Fig. 1), but with very much differing peat column stratigraphy (Figs. 2, 3) and peat column botanical composition as well as decomposition degree. The major part of the bog volume of Kronu-Dzelves bog consists from relatively homoge- 


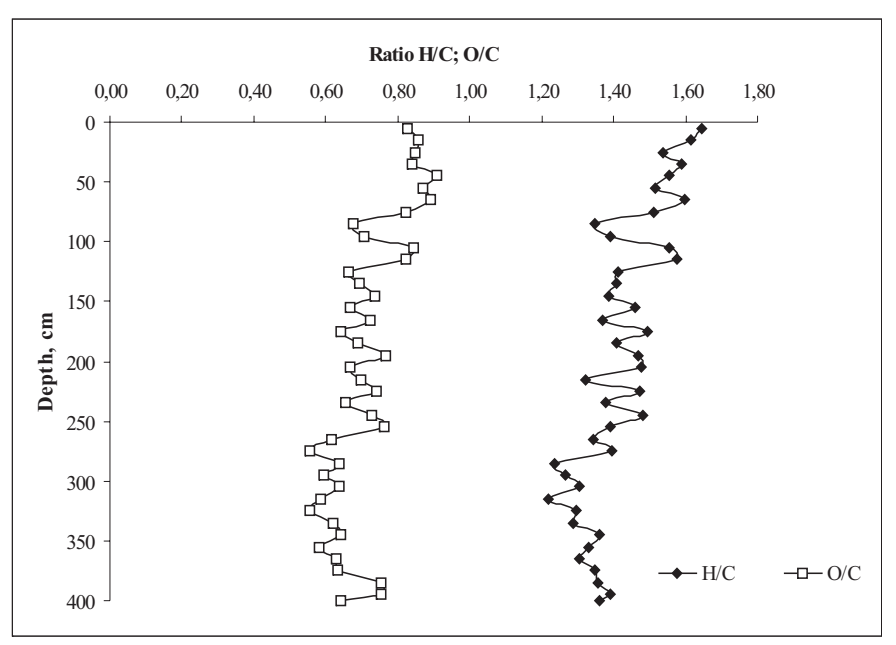

Fig. 5. Element ratio in peat from Eipurs bog.

neous sphagnum peat with a comparatively low decomposition degree, while the composition of the Eipurs bog peat is very much heterogeneous and reflects high variability of local bog development conditions.

Basic peat properties can be analysed using peat elemental (C, H, N, O, S) composition. The elemental composition of peat in the Eipurs bog is comparatively variable and reflects the changes in the peat decomposition degree and peat type. $\mathrm{C}$ concentration in the peat increases starting from a depth of $1 \mathrm{~m}$ and reaches a level of $53 \%$ at about $3 \mathrm{~m}$ depth and then again decreases. $\mathrm{H}$ concentrations demonstrate significantly higher variability. $\mathrm{N}$ concentrations are higher in the upper and lower horizons of the bog and demonstrate increased values coinciding with the changes in the peat composition and formation conditions, which might be associated with changes in the peat botanical composition and decomposition degree. S concentrations are significantly lower just in few upper centimetres of the peat bog, but comparatively stable along the peat column. The elemental composition (Table 1) of Kronu Dzelves bog is very much different and largely reflects the peat column composition: the $\mathrm{C}$ content in the upper layers is much lower $(\sim 45 \%)$ and comparatively uniform up to a depth of $3.25 \mathrm{~m}$, but then rapidly increases reaching $55 \%$ for highly decomposed peat.

The elemental ratio is much more informative than elemental composition of peat is (Table 1, Fig. 5. C/N ratio can be considered as an good index of the humification process due to specific microbial activity in anaerobic, acidic environment and enrichment of the peat mass with nitrogen containing compounds of bacterial origin (Borgmark, 2005a). This ratio can be efficiently used as a measure of peat degradation. Decreasing $\mathrm{C} / \mathrm{N}$ ratios indicate increasing peat decomposition (due microbial decay) and vice versa. The $\mathrm{H} / \mathrm{C}$ ratio is an index of molecular complexity (but at the same time of aromaticity) and ranges from 1.6 to 1.2 (Anderson and Hepburn, 1987). It is relatively constant with depth; below $50 \mathrm{~cm}$, it decreases. On the other hand, $\mathrm{O} / \mathrm{C}$ ratio is considered an indicator of carbohydrate and carboxylic contents and can be directly related to aromatisation of the or-

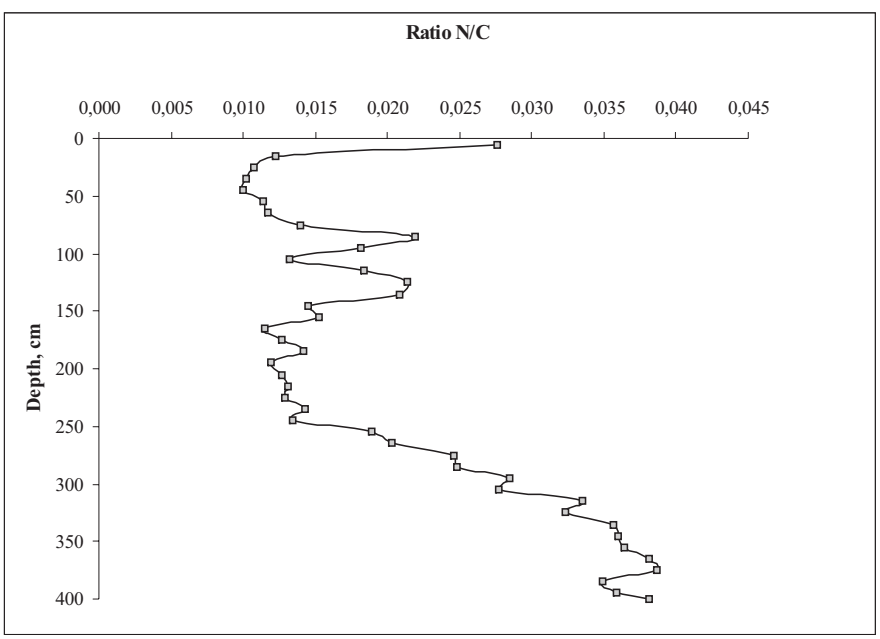

ganic matter forming peat (Anderson and Hepburn, 1987). $\mathrm{O} / \mathrm{C}$ ratio decreases with depth, however in layers with higher decomposition degree also values of this indicator are high.

Elemental analysis data can be used also for calculation of hydrogen deficiency $\phi$ and degree of oxidation $\omega$ indexes (Fong and Mohamed, 2007). However in this case these indexes have only weak relation with the high variability of peat properties in Eipurs bog peat core and peat hydrogen deficiency $\phi$ and degree of oxidation $\omega$ can be considered as relatively homogeneous (Fig. 6).

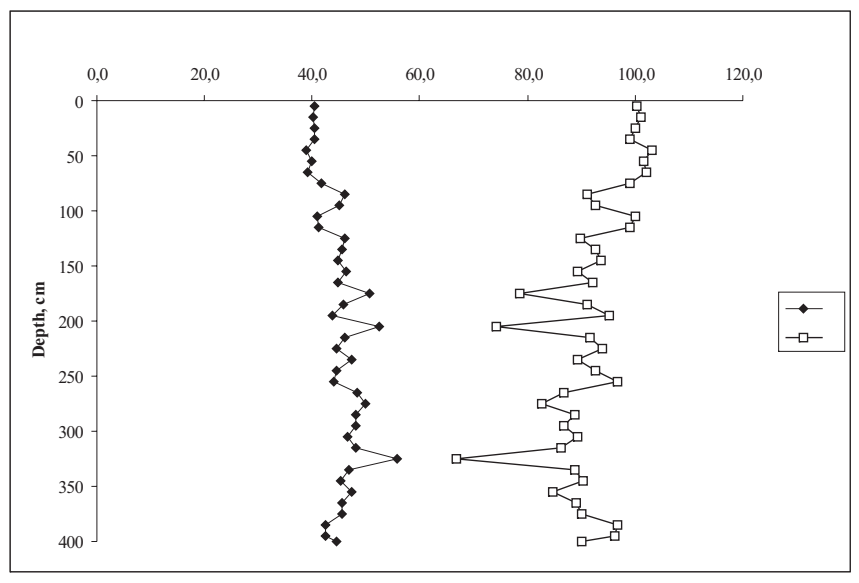

Fig. 6. Index of hydrogen deficiency $\phi$ and degree of oxidation $\omega$ versus depth in peat from Eipurs bog.

The $\mathrm{E}_{4} / \mathrm{E}_{6}$ ratio is often used to describe the extent of condensation of the aromatic C-containing structures; low ratios reflect high degrees of condensation of aromatics, while high ratios mean the presence of large quantities of aliphatic structures and low amounts of condensed aromatics (Chen et al., 1977). This ratio is also inversely related to the degree of aromaticity and acidity (Uyguner et al., 2004).

In the present study, the variability of the $\mathrm{E}_{4} / \mathrm{E}_{6}$ ratios in the peat profile of the Eipurs bog was relatively high (Fig. 7) and can be related to the transformation processes of organic matter within peat profiles. 


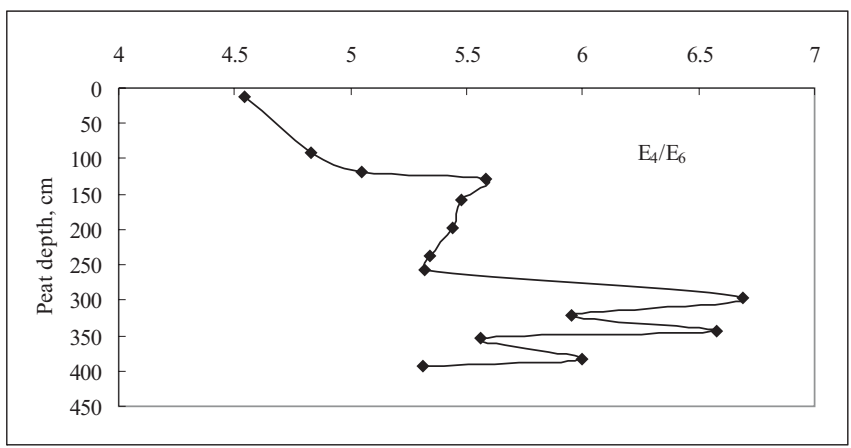

Fig. 7. Sectral absorption ratio $\mathrm{E}_{4} / \mathrm{E}_{6}$ versus depth in peat from Eipurs bog.

Absorption at $540 \mathrm{~nm}$ in the UV-Vis spectra of peat alkaline extracts can be used as an simple indicator of humification process as has been suggested and recently improved by Borgmark (2005a). This humification index demonstrates the expected differences (Fig. 8) when used for description of Kronu-Dzelves and Eipurs bogs and the changes can be associated both with the peat decomposition degree and with the differences in peat composition.

In order to provide reliable and quantity information about the diagenesis of peat, we carried out further studies of the dependence of the peat humification indicators (humific- ation indexes) on the peat decomposition (correspondingly peat age, depth and decomposition degree (Figs. 9, 10).

As it can be seen from Figure 9, the peat decomposition is very well and statistically significantly correlated with the humification index according to Borgmark (2005b) and humification degree, an index suggested by Šire et al. (2008). Correlation between fluorescence intensity ratios fluorescence intensities $\left(\mathrm{I}_{380} / \mathrm{I}_{330}\right.$ and $\left.\mathrm{I}_{460 /} \mathrm{I}_{380}\right)$ is much poorer. Both of these humification indexes describe basic changes in the peat properties and are well correlated with the elemental ratios of the peat in the peat cores, thus depicting changes of peat organic materials during humification of living organic matter, and can be suggested for characterisation of humification process also in other environments.

The conclusions are that studies of living organic matter humification are essential for understanding of the carbon biogeochemical cycle. From this perspective, the study of peat properties of peat cores can help to identify the links between peat age, decomposition degree, peat properties, peat botanical composition and peat properties An important tool in carbon biogeochemical cycle studies can be humification indicators, which might provide new understanding of chemical and biochemical processes behind the humification.
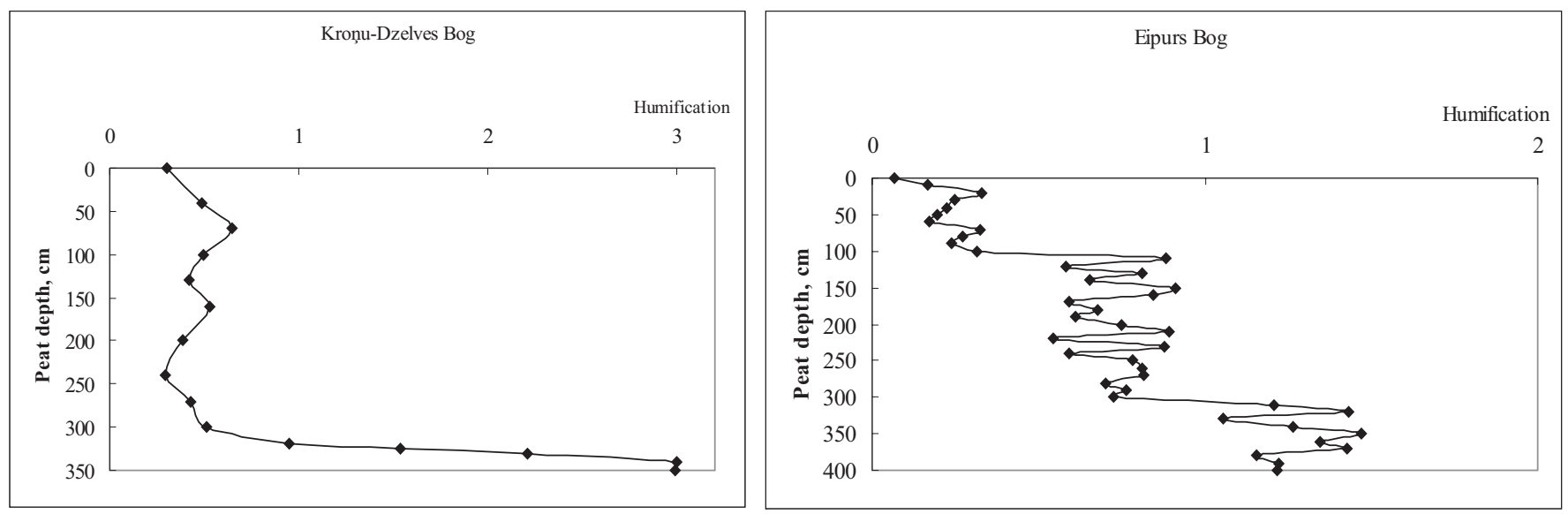

Fig. 8. Changes of the Humification Index according to Borgmark (2005a) (adsorption of peat extract at $540 \mathrm{~nm}$ ) versus depth in peat from Eipurs bog.
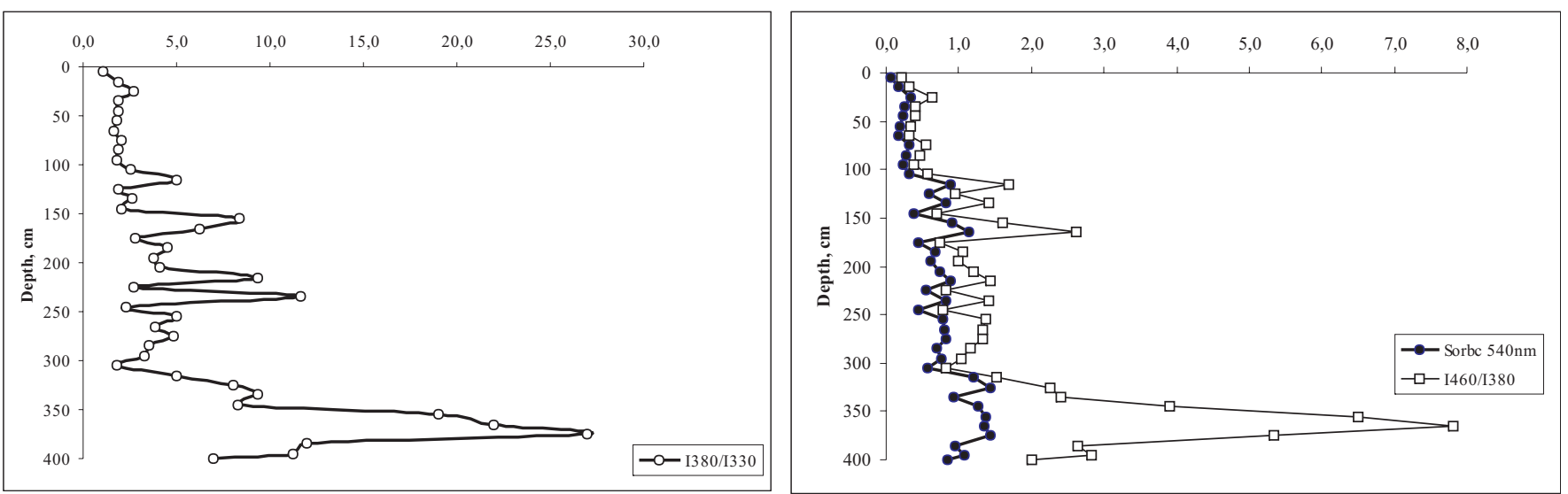

Fig. 9. Changes of the Humification Index according to Borgmark (2005a) (adsorption of peat extract at $540 \mathrm{~nm}$ ) and ratios of fluorescence indexes ( $\mathrm{I}_{380} / \mathrm{I}_{330}$ and I $\left.460 / \mathrm{I}_{380}\right)$ versus depth in peat from Eipurs bog. 

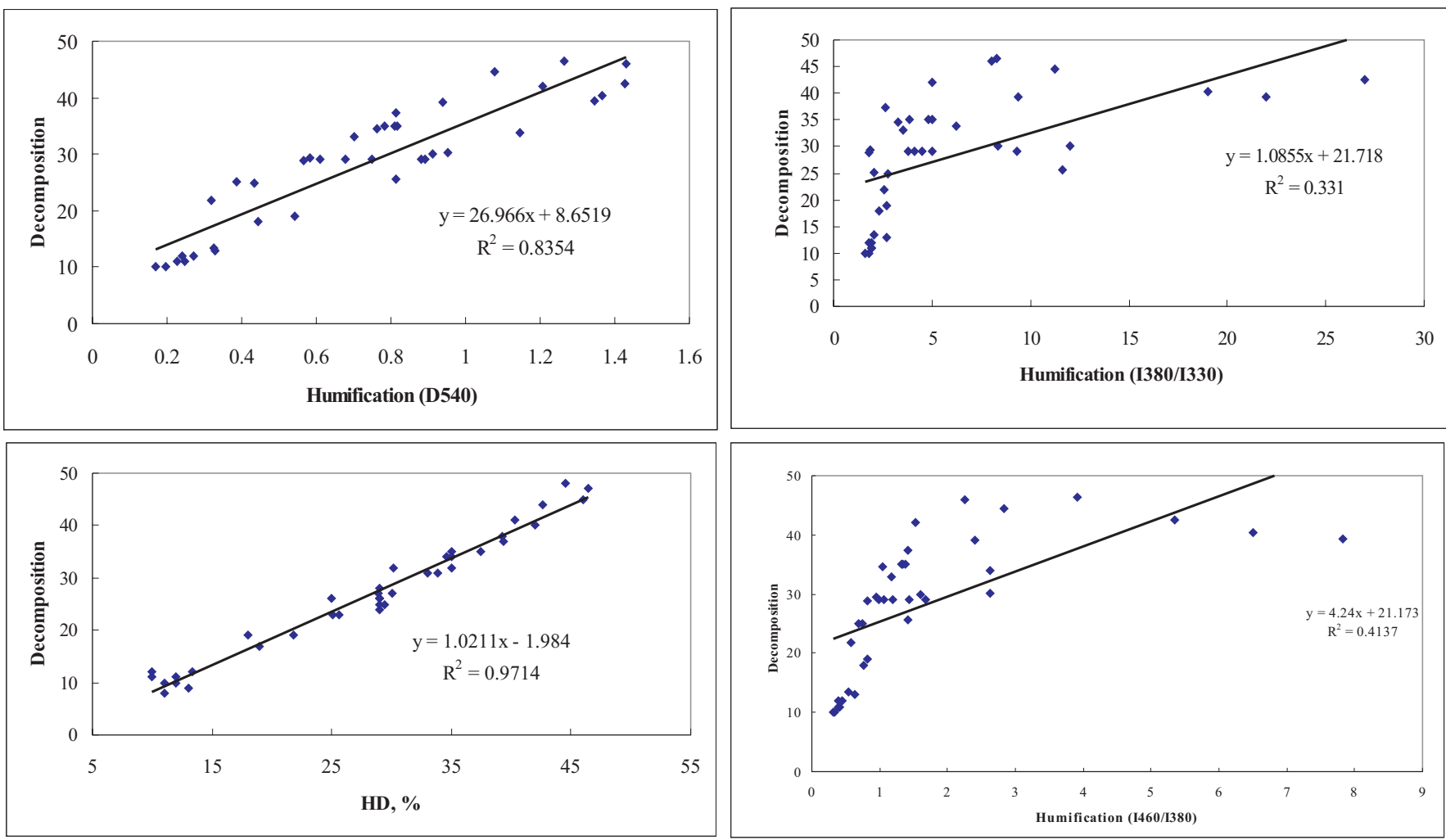

Fig. 10. Correlation between peat decomposition (\%, Eipurs and Kroṇu-Dzelves bog) and humification indexes (Humification Index according to Borgmark D540, Humification degree $\mathrm{HD}$, and fluorescence intensity ratios I $380 / \mathrm{I}_{330}$ and I $460 / \mathrm{I}_{380}$ )
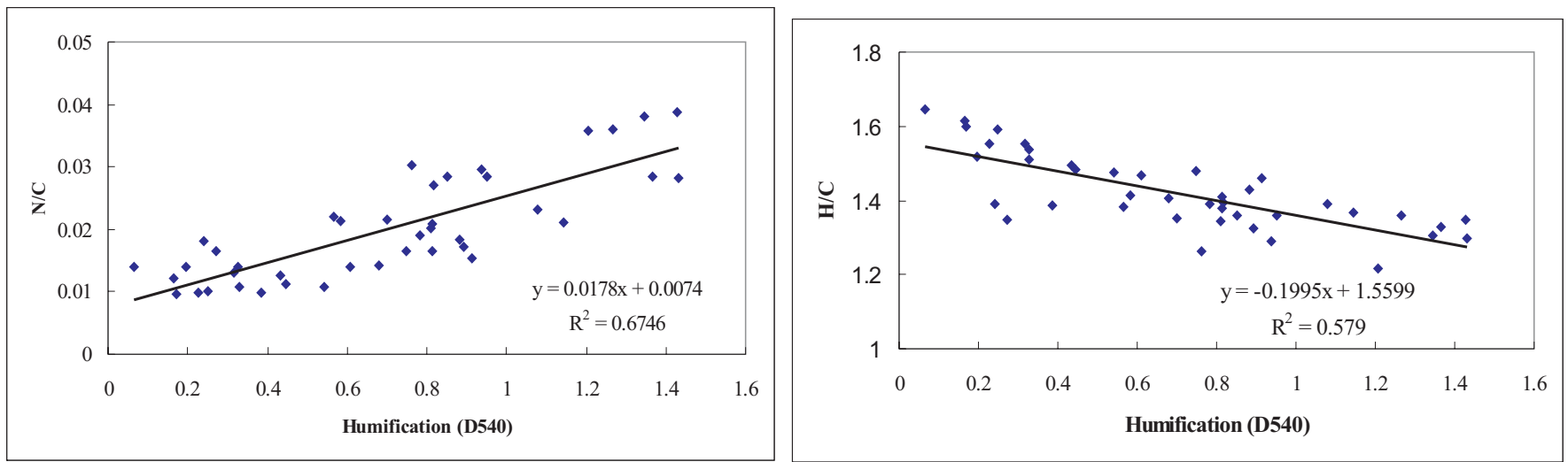

Fig. 11. Correlation between Humification Index (Eipurs and Kroņu-Dzelves bog) according to Borgmark (D540) and elemental ratio of peat N/C, H/C

The transformation process can be described using multiproxy analysis of peat elemental composition, elemental ratios and spectral characterization of the peat organic matter and peat alkaline extracts. This approach supports not only better understanding of the peat properties but also their relation to both peat decomposition processes and original living organic matter. Multiproxy study of peat properties supports development of peat humification indicators.

\section{ACKNOWLEDGEMENTS}

The authors are grateful to Dr. Enn Kaup (Institute of Geology, Estonia) for the determination of peat age using ${ }^{14} \mathrm{C}$ analysis, A. Dinkite (Balt-Ost Geo) for the analysis of botanical composition and decomposition degree.

\section{REFERENCES}

Anderson, H., Hepburn, A. (1986). Variation of humic substances within peat profile. In: Peat and Water (pp. 177-194). C.H. Fuchsman (ed.). N.Y.: Academic Press.

Borgmark, A. (2005a). Holocene climate variability and periodicities in south-central Sweden, as interpreted from peat humification analysis. Holocene, 15(3), 387-395.

Borgmark, A. (2005b). The colour of climate: Changes in peat decomposition as a proxy for climate change - a study of raised bogs in South-central Sweden. PhD thesis, Stockholm: Stockholm University.

Blackford, J.J., Chambers, F.M. (1993). Determining the degree of peat decomposition for peat-based paleoclimatic studies. Int. Peat J., 5, 7-24. 
Brown, P.A., Gill, S.A., Allen, S.J. (2000). Metal removal from wastewater using peat. Water Res., 34(16), 3907-3916.

Caseldine, C.J., Baker, A., Charman, D.J., Hendon, D. (2000). A comparative study of optical properties of $\mathrm{NaOH}$ peat extracts: Implications for humification studies. Holocene, 10(5), 649-658.

Chapman, S.J., Campbell, C.D., Fraser, A.R., Puri, G. (2001). FTIR spectroscopy of peat in and bordering Scots pine woodland: Relationship with chemical and biological properties. Soil Biol. Biochem., 33, 1193-1200.

Chen, Y., Senesi, N., Schnitzer, M. (1977). Information provided on humic substances by $\mathrm{E}_{4} / \mathrm{E}_{6}$ ratios. Soil Sci. Soc. Amer. J., 41(2), 352-358.

Cocozza, C., D’Orazio, V., Miano, T.M., Shotyk, W. (2003). Characterization of solid and aqueous phases of a peat bog profile using molecular fluorescence spectroscopy, ESR and FT-IR, and comparison with physical properties. Org. Geochem., 34, 49-60.

Fong, S.S., Mohamed, M. (2007). Chemical characterization of humic substances occurring in the peats of Sarawak, Malaysia. Org. Geochem., 38(6), 967-976

Ghaly, R. A., Pyke, J. B., Ghaly, A. E., Ugursal, V. I. (1999). Remediation of diesel-oil-contaminated soil using peat. Energy Sources, A: Recovery, Utilization, and Environmental Effects, Chemosphere, 21(9), 785-799.

Yeloff, D., Mauquoy, D. (2006). The influence of vegetation composition on peat humification: Implications for paleoclimatic studies. Boreas, 35, 662-673.

Moore, P.D., Webb, J.A. (1978). An Illustrated Guide to Pollen Analysis. Hodder and Stought, London. $133 \mathrm{pp}$.

Kuder, T., Kruge, M.A., Shearer, J.C., Miller, S.L. (1998). Environmental and botanical controls on peatification: A comparative study of two New Zealand restiad bogs using Py-GC/MS, petrography and fungal analysis. Int. J. Coal Geol., 37, 3-27.
Von Post, L., Granlund, E. (1926). Södra Sveriges torvtillgångar 1 [Southern Sweden turf resources]. Sver. Geol. Unders., C335 19(2), 1-127 (in Swedish).

Milori, D.M.B.P., Neto, L.M., Bayer, C., Mielniczuk, J., Bagnato, V.S. (2002). Humification degree of soil humic acids determined by fluorescence spectroscopy. Soil Sci., 167(11), 739-749.

Steiner, G.M. (ed.). (2005). Moore von Siberian bis Feurland. Biologiezentrum der OÖ Landesmuseum: Linz (Austria).

Tan, K. H., (2005). Soil Sampling, Preparation, and Analysis. Second Edition. Taylor \& Francis Group, New York. 623 pp.

Šìre, J., Kḷaviņš, M., Purmalis, O., Melecis, V. (2008). Experimental study of peat humification indicators. Proc. Latv. Acad. Sci., Section B, 62(1/2), $18-27$.

Zaccone, C., Miano, T.M., Shotyk, W. (2007). Qualitative comparison between raw peat and related humic acids in an ombrotrophic bog profile. Org. Geochem., 38, 151-160.

Zicheng, Yu., Vitt, D.H., Campbell, I.D., Apps, M.J. (2003). Understanding Holocene peat accumulation pattern of continental fens in western Canada. Can. J. Bot., 81, 267-282.

Uyguner, C.S., Hellriegel, C., Otto, W., Larive, C.K. (2004). Characterization of humic substances: Implications for trihalomethane formation. Anal. Bioanal. Chem., 378, 1579-1586.

Лиштван, И. И., Король, Н. Т. (1975). Основные свойства торфа и методы их определения [Basic Properties of Peat and Methods for Their Determination]. Минск: Наука и Техника. 320c. (in Russian).

Тюремнов С.Н. (1976). Торфяные месторождения [Peat Deposits]. Москва: Недра. 488 с. (in Russian).

Received 10 June 2009

\section{KŪDRAS HUMIFIKĀCIJAS RAKSTURA ATKARĪBA NO TĀS İPAŠİBĀM DIVU AUGSTO PURVU KŪDRAS KOLONNAS ANALĪZES PIEMĒRĀ}

Oglekḷa bioğeoķīmiskās aprites cikla ietvaros notiekošo procesu izpētei svarīgi ir izprast dzīvās organiskās vielas pārvērtību raksturu, notiekot tās sadalīšanās - humifikācijas procesiem. Šī darba mērkis ir pētīt kūdras īpašības tās kolonnā atškirīgas uzbūves augstā tipa purvos atkarībā no humifikācijas procesu rakstura, kā arī attīstīt risinājumus humifikācijas procesa raksturošanai. Pētījumā pierādīts, ka kūdras elementsastāva un īpašību analīze ļauj atsegt kopsakarības starp kūdras humifikācijas procesiem, kūdru veidojošo augu sastāvu un izstrādāt humifikācijas indeksus kūdras īpašību raksturošanai. Ieteikts humifikācijas pakāpes noteikšanai izmantot kopējās organiskās vielas kūdrā un humifikācijas gaitā veidoto humusvielu attiecību, kā arī kūdras sārmaina ekstrakta sorbcijas vērtību pie $540 \mathrm{~nm}$. 